\title{
Daya Tarik Gelombang Bono Sebagai Objek Wisata Unggulan di Kabupaten Pelalawan
}

\author{
RINI YULIARTI \\ $\&$ \\ DODDY SAPUTRA
}

Dosen tetap Sekolah Tinggi Pariwisata Riau

\begin{abstract}
The Travel Attractions Bono was amazing and unmatched so as to attract tourists to come to the District Pelalawan. For world surfers (surfers) and tourists from outside, Waves Bono Kampar is an amazing discoveries reveal even the world selencar remarkable for "Bono Kampar ". Bono first waves or wave Kampar River as a frightening figure, but now it become a mainstay for Palalawan Tourism and Riau Province. District Government strategy to develop tourism area Bono As a mainstay of tourism in Pelalawan had done well but not maximized. The strategy that has been done to develop the region are: Conducting regional cultural arts performances Bono, Bono waves Held promotional events, exhibitions Conducting tourism and tourism facilities and infrastructure.
\end{abstract}

Keywords: Fascination, Attractions Bono

\section{PENDAHULUAN}

Salah satu objek wisata yang terkenal di Kabupaten Pelalawan untuk saat ini adalah Wisata Bono yang merupakan Gelombang Bono. Gelombang ini menjadi perbincangan hangat saat ini. Keberadaan fenomena ombak bono di Teluk Meranti, Kabupaten Pelalawan ini sudah tersebar sampai ke manca negara.Namun, barangkali masih banyak masyarakat Riau yang belum mengetahui tentang keberadaan bono sungai Kampar ini. Objek Wisata Bono terletak di Desa Teluk Meranti, sepanjang Sungai Kampar dan Sungai Rokan. Bono merupakan fenomena alam yang menakjubkan, ketika air sungai pasang maka air sungai akan menggelombang, berombak besar. Tinggi gelombang tersebut mencapai 6 meter. Air laut mengalir masuk dan bertemu dengan air sungai Kampar sehingga terjadi gelombang dengan kecepatan yang cukup tinggi, dan menghasilkan suara seperti suara guntur dan suara angin kencang.

Bono yang terdapat di daerah Kuala Kampar ini merupakan pasangan jantan dari Bono Betina yang terdapat di Sungai Rokan. Bono yang terdapat di Sungai Kampar Kecamatan Kuala Kampar kabupaten Pelalawan sudah dianggap sebagai hal yang biasa bagi masyarakat sekitar di Kuala Kampar, mereka disana menganggap Bono sebagai arena bermain untuk menguji ketangkasan berperahu. Selama ini Bono Kampar adalah sosok yang menakutkan, tidak ada satupun yang bisa selamat dari Ombak Bono, kapal Tongkang Kayu RAPP saja karam oleh ganasnya Ombak Bono Sungai Kampar. Keberanian para peselancar dunia bermain-main di atas gelombang bono berlahan mengikis ketakutan masyarakat di pesisir Kuala Kampar. Bahkan kini, ada wahana wisata baru yang bisa digarap Namanya bermain bono. Gelombang paling tinggi terjadi saat bulan besar (bulan purnama). Pada musim pasang tinggi, gelombang sungai Kampar bisa mencapai 4-6 meter yang membentang dari tepi ke tepi menutupi keseluruhan badan sungai. Hal yang menarik turis ke objek wisata ini adalah kegiatan berenang, memancing, naik sampan, 
dan kegiatan lainnya. Fenomena alam Bono yang berupa gelombang di Sungai Kampar, dahulunya ditakuti masyarakat yang ada dialiran Sungai Kampar di Kecamatan Teluk Meranti Kabupaten Pelalawan, ternyata menjadi fenomena yang menyenangkan bagi beberapa orang dari manca Negara yang gemar melakukan aktifitas surfing sekaligus membuktikan bahwa gelombang ini mampu ditaklukan dan dapat menjadi sesuatu yang mengasyikan bukan hanya dilihat melainkan dimainkan dengan menggunakan papan selancar. Turis asing telah beberapa kali datang, hingga menarik minat turis lainnya untuk turut merasakan gelombang Bono yang menurut mereka cukup dahsyat ini. Bahkan ada beberapa diantaranya yang merupakan surfer dunia yang telah mencobanya sendiri. Beberapa surfer dunia yang telah datang untuk mencoba Gelombang Bono ini berasal dari berbagai negara seperti Peselancar dari Belgia, Selandia Baru, Jerman, dan Perancis.

Fasilitas yang ada di Kawasan Bono ini masih teramat kurang sehingga dibutuhkan campur tangan Pemerintah Kabupaten Pelalawan dan investor. Fasilitas yang tersedia hanya berupa tiga anjungan yang dipergunakan untuk menonton atraksi bono yang tidak terlalu besar, taman rekreasi yang belum terawat rapi dikawasan Bono tersebut. Untuk fasilitas penginapan belum ada yang bersifat permanen yang dibangun oleh Pemkab Pelalawan maupun oleh investor. Jika para wisatawan termasuk peselancar membutuhkan penginapan mereka menggunakan rumah-rumah penduduk yang cukup banyak untuk disewakan.

Gelombang Bono memiliki potensi pariwisata yang cukup besar. Gelombang ini merupakan gelombang yang dihasilkan oleh gelombang pasang yang diakibatkan adanya bulan purnama. Ini hanya terjadi di Sungai Kampar di Indonesia. Gelombang ini pun terbilang unik karena memiliki gelombang berlapis. Gelombang Bono hanya muncul beberapa hari setiap bulannya pada Bulan November tiap tahunnya. Hadirnya hanya pada siang hari antara pukul 11.00 WIB hingga 13.00 WIB. Selain berselancar dan bermain bono, potensi wisata lainnya pun bermunculan di tempat itu. Misalnya pada tanggal 26-29 September lalu, Pemerintah Kabupaten Pelalawan melaksanakan Pagelaran Seni Budaya Bono. Helat budaya itu sengaja dirancang dan dikemas, bertepatan kedatangan para peselancar yang selama sepekan di akhir September berada di tempat tersebut.

Jika melihat dari potensi yang dimiliki oleh Gelombang Bono ini maka hal itu sesuai dengan peraturan Mentri Kebudayaan dan Pariwisata PM.37/UM.001/MKP/07 tentang kriteria dan keunggulan destinasi pariwisata sekurang-kurangnya meliputi: Ketersediaan semberdaya dan daya tarik wisata; Fasilitas pariwisata dan fasilitas umum; Aksesibilitas; Kesiapan dan keterlibatan masyarakat; Potensi pasar; Posisi strategi pariwisata dalam pembangunan daerah. Dengan melihat betapa besarnya potensi Gelombang Bono untuk menarik minat wisatawan yang datang ke Kabupaten Pelalawan maka sebaiknya Pemerintah Kabupaten dapat mengembangkan potensi wisata ini. Jika wisata ini dapat dikelola dengan baik maka menjadi keunggulan wisata di Kabupaten Pelalawan yang akan membuat keuntungan yang besar pula bagi Pendapatan Asli Daerah (PAD) terutama pendapatan masyarakat tempatan. Gelombang Bono ini dapat dijadikan wisata unggulan bagi Kabupaten Pelalawan untuk menarik wisatawan yang lebih banyak lagi dikarenakan tidak akan ditemukan hal serupa di tempat lain. Dengan dijadikannya Wisata Bono ini sebagai wisata unggulan maka seharusnya fasilitas, sarana dan prasarana tempat ini lebih di benahi oleh Pemerintah Kabupaten sehingga wisatawan yang datang berkunjung dapat menikmatinya dengan puas.

Sebagai kerangka pemikiran dalam penulisan ini perlu adanya landasan teori yang mendukung penulisan ini. Oleh karena itu penulis akan mengemukakan beberapa teori yang ada relevansinya dengan penulisan ini. Ekowisata adalah suatu jenis pariwisata yang kegiatannya 
semata-mata menikmati aktivitas yang berkaitan dengan lingkungan alam dengan segala bentuk kehidupan dalam kondisi apa adanya dan berkecenderungan sebagai ajang atau sarana lingkungan bagi wisatawan dengan melibatkan masyarakat di sekitar kawasan proyek wisata. (Entin Supriatin, "Ada Lima Unsur dalam Pengelolaan Ekowisata”, dalam Berita Wisata edisi 21 Oktober 1997).

Ekowisata adalah wisata yang berbasis alam yang berkaitan dengan pendidikan dan pemahaman lingkungan alam dan dikelola dengan prinsip berkelanjutan (sustainable). Australian National Ecotourism Strategy, (1994:24). Ekowisata adalah kegiatan petualangan, wisata alam, budaya, dan alternatif yang mempunyai karakteristik : Adanya pertimbangan yang kuat pada lingkungan dan budaya lokal; Kontribusi positif pada lingkungan dan sosial-ekonomi lokal; Pendidikan dan pemahaman, baik untuk penyedia jasa maupun pengunjung mengenai konservasi alam dan lingkungan. Ekowisata adalah perjalanan yang dapat dipertanggungjawabkan, kekawasan alam dengan memelihara lingkungan yang bisa menopang kesejahteraan penduduk setempat, Blangey dan Wood in Wall (1995:15)

Ekowisata adalah wisata ke alam perawan yang relatif belum terjamah atau tercemar dengan tujuan khusus mempelajari, mengagumi, serta perwujudan bentuk budaya yang ada didalam kawasan tersebut. Hector Cebollos Lascurain (1997:20). Ecotourism envolvestraveling to relatively undisturb natural areas with the specifik objective of studiying, admiring, and enjoying the sceneryand its wild plants an animals as well as any existing cultural aspect found in those area. World Tourism Organization (WTO) dan United Nations Environtment Program (UNEP). Ekowisata sebagai salah satu bentuk perjalanan wisata yang bertujuan ke kawasan alami yang dilakukan dengantujuan mengkonservasi lingkungan dan melestariakan kehidupan dan kesejahteraan penduduk setempat. The Ecotourism Society (2002:10). Masih menurutnya Ecotourism adalah sebuah ide, dan bukan merupakan sesuatu yang mudah untuk dilakukan atau dicapai, karena hal tersebut memadukan 4 komponen (natural, community, culture, and economic).

Ekowisata adalah pariwisata yang menyangkut perjalanan ke kawasan alam yang secara relativ belum terganggu dengan tujuan untuk mengagumi, meneliti, dan menikmati pemandangan indah seperti : tumbuh-tumbuhan, binatang liar, termasuk unsur kebudayaan yang ditemukan di daerah tujuan. Ceballos - Lascurian, (1995: 30). Ekowisata adalah sebuah program studi yang terdapat pada fakultas kehutanan, institut pertanian bogor (IPB) jurusan konservasi sumberdaya hutan dan ekowisata dan bertahan selama 5 angkatan, yaitu angkatan 37 sampai dengan 41, setelah itu mengalami peralihan dibawah naungan politeknik IPB pada tahun ajaran 2005/2006, menurut Ghufron Azhar (2005:34).

Pengembangan ekowisata sangat dipengaruhi oleh keberadaan unsur-unsur yang harus ada dalam pengembangan itu sendiri, yaitu Sumber daya alam, peninggalan sejarah dan budayaKekayaan keanekaragaman hayati merupakan daya tarik utama bagi pangsa pasar ekowisata sehingga kualitas, keberlanjutan dan pelestarian sumber daya alam, peninggalan sejarah dan budaya menjadi sangat penting untuk pengembangan ekowisata. Ekowisata juga memberikan peluang yang sangat besar untuk mempromosikan pelestarian keanekaragaman hayati Indonesia di tingkat internasional, nasional maupun lokal. Menurut Ashrama (2003: 12) mengatakan bahwa ekowisata sangat terkait dengan hal-hal seperti: Masyarakat, Pada dasarnya pengetahuan tentang alam dan budaya serta daya tarik wisata kawasan dimiliki oleh masyarakat setempat. Oleh karena itu pelibatan masyarakat menjadi mutlak, mulai dari tingkat perencanaan hingga pada tingkat pengelolaan. Pendidikan, Ekowisata meningkatkan kesadaran dan apresiasi terhadap alam, nilai-nilai peninggalan sejarah dan budaya. Ekowisata memberikan nilai tambah 
kepada pengunjung dan masyarakat dalam bentuk pengetahuan dan pengalaman. Nilai tambah ini mempengaruhi perubahan perilaku dari pengunjung, masyarakat dan pengembang pariwisata agar sadar dan lebih menghargai alam, nilai-nilai peninggalan sejarah dan budaya. Pasar, Kenyataan memperlihatkan kecendrungan meningkatnya permintaan terhadap produk ekowisata baik di tingkat internasional dan nasional. Hal ini disebabkan meningkatnya promosi yang mendorong orang untuk berperilaku positif terhadap alam dan berkeinginan untuk mengunjungi kawasan-kawasan yang masih alami agar dapat meningkatkan kesadaran, penghargaan dan kepeduliannya terhadap alam, nilai-nilai sejarah dan budaya setempat. Ekonomi, Ekowisata memberikan peluang untuk mendapatkan keuntungan bagi penyelenggara, pemerintah dan masyarakat setempat, melalui kegiatan-kegiatan yang non ekstraktif, sehingga meningkatkan perekonomian daerah setempat. Penyelenggaraan yang memperhatikan kaidah-kaidah ekowisata mewujudkan ekonomi berkelanjutan. Kelembagaan, Pengembangan ekowisata pada mulanya lebih banyak dimotori oleh Lembaga Swadaya Masyarakat, pengabdi masyarakat dan lingkungan. Hal ini lebih banyak didasarkan pada komitmen terhadap upaya pelestarian lingkungan, pengembangan ekonomi dan pemberdayaan masyarakat secara berkelanjutan. Namun kadang kala komitmen tersebut tidak disertai dengan pengelolaan yang baik dan profesional, sehingga tidak sedikit kawasan ekowisata yang hanya bertahan sesaat. Sementara pengusaha swasta belum banyak yang tertarik menggarap bidang ini, karena usaha seperti ini dapat dikatakan masih relatif baru dan kurang diminati karena harus memperhitungkan social cost dan ecological-cost dalam pengembangannya.

Masalah yang mendasar adalah bagaimana membangun pengusaha yang berjiwa pengabdi masyarakat dan lingkungan atau lembaga pengabdi masyarakat yang berjiwa pengusaha yang berwawasan lingkungan. Pilihan kedua, yaitu mengembangkan lembaga pengabdi masyarakat yang berjiwa pengusaha berwawasan lingkungan dilihat lebih memungkinkan, dengan cara memberikan pelatihan manajemen dan profesionalisme usaha. Untuk hal ini diperlukan bentuk kerja sama dan kemitraan yang nyata yang bersifat lintas sektor, baik ditingkat lokal, nasional, bahkan jika memungkinkan tingkat internasional, secara sinergis saling menguntungkan, tidak bersifat eksploitatif, adil dan transparan dengan pembagian tugas yang jelas.

Aktualisasi dari kerja sama ini, juga dimungkinkan bagi daerah yang akan mengembangkan Daerah Tujuan Ekowisata dengan memanfaatkan potensi Taman Wisata Alam dan Taman Nasional yang ada di wilayahnya. Pemerintah daerah setempat dapat memprakarsai pembentukan suata "Badan" ("board") yang akan mengelola ekowisata secara profesional. Menurut The International Ecotourism Society (2002) dalam Subadra (2007:25) Mendifinisikan ekowisata sebagai berikut: Ecotourism is "responsible travel to natural areas that conserves the environment and sustains the well-being of local people." Dari definisi ini, disebutkan bahwa ekowisata merupakan perjalanan wisata yang berbasiskan alam yang mana dalam kegiatannya sangat tergantung kepada alam, sehingga lingkungan, ekosistem, dan kerifan-kearifan lokal yang ada di dalamnya harus dilestarikan keberadaanya.

Dalam perkembangan kepariwisataa secara umum, muncul pula istilah sustainable tourism atau "wisata berkelanjutan". Wisata berkelanjutan dipandang sebagai suatu langkah untuk mengelola semua sumber daya yang secara sosial dan ekonomi dapat dipenuhi dengan memelihara integritas budaya, proses-proses ekologi yang mendasar, keragaman hayati dan unsur-unsur pendukung kehidupan lainnya", menurut Urquico, (1998) dalam Santoso (2003 : 26). 
Konsep wisata yang berbasis ekologi atau yang lebih dikenal dengan Ekowisata, menurut Fandeli (2000: 18), dilatarbelakangi dengan perubahan pasar global yaitu pertumbuhan ekonomi yang tinggi pada negara-negara asal wisatawan dan memiliki ekspektasi yang lebih mendalam dan lebih berkualitas dalam melakukan perjalanan wisata. Konsep wisata ini disebut wisata minat khusus , Fandeli (2000).Wisatawan minat khusus umumnya memiliki intelektual yang lebih tinggi dan pemahaman serta kepekaan terhadap etika, moralitas dan nilai-nilai tertentu, sehingga bentuk wisata ini adalah pencarian pengalaman baru, Fendeli, (2000: 34).

Menurut Fandeli $(2000$; 37) Secara umum basis pengembangan wisata minat khusus meliputi: Aspek alam seperti flora, fauna, fisik geologi, vulkanologi, hidrologi, hutan alam atau taman nasional. Objek dan daya tarik wisata budaya yang meliputi budaya peninggalan sejarah dan budaya kehidupan masyarakat. Potensi ini selanjutnya dapat dikemas dalam bentuk wisata budaya peninggalan sejarah, wisata pedesaan dan sebagainya dimana wisatawan memiliki minat untuk terlibat langsung dan berinteraksi dengan budaya masyarakat setempat serta belajar berbagai hal dari aspek-aspek budaya yang ada.

Ekowisata merupakan perjalanan wisata ke suatu lingkungan baik alam yang alami maupun buatan serta budaya yang ada yang bersifat informatif dan partisipatif yang bertujuan untuk menjamin kelestarian alam dan sosial-budaya. Ekowisata menitikberatkan pada tiga hal utama yaitu; keberlangsungan alam atau ekologi, memberikan manfaat ekonomi, dan secara psikologi dapat diterima dalam kehidupan sosial masyarakat. Jadi kegiatan ekowisata secara langsung memberi akses kepada semua orang untuk melihat, mengetahui, dan menikmati pengalaman alam, intelektual dan budaya masyarakat lokal (Khan, 2003:44).

Muntahan lahar dan awan panas dari kawah gunung Merapi di tahun 2006 sampai 2007 merupakan momen yang menarik juga untuk dijadikan Objek dan Daya Tarik Wisata Alam. Momen ini jarang terjadi dan dalam kurun waktu yang lama. Terlepas dari fenomena tersebut merupakan suatu bencana alam, namun tantangan bagi kita untuk mengemasnya sehingga memberikan nilai kemanfaatan terhadap sifat Objek dan Daya Tarik Wisata Alam yang Perisable ini.

Sifat dan karakter Objek dan Daya Tarik Wisata Alam yang Non Recoverable membawa konsekwensi bahwa di dalam pengelolaan Objek dan Daya Tarik Wisata Alam hendaknya diperhatikan betul permasalahan daya dukung Objek dan Daya Tarik Wisata Alam tersebut. Di sinlah perlunya pengelolaan yang berimbang antara tujuan ekonomi dan lingkungan alam Objek dan Daya Tarik Wisata Alam tersebut. Jika pengelolaannya melebihi daya dukung baik sarana maupun jumlah pengunjung maka akan terjadi perubahan eko sistem, akan sulit untuk diperbaiki, bagaimanapun usaha perbaikan itu tidak akan bisa mengembalikan kepada ekosistem yang asli. Upaya yang ideal adalah menjaga keseimbangan ekosistem tersebut agar tidak melebihi daya dukung lingkungan Objek dan Daya Tarik Wisata Alam bersangkutan.

Potensi Obyek dan Daya Tarik Wisata Alam yang dimiliki Indonesia, antara lain berupa keanekaragaman hayati, keunikan dan keaslian budaya tradisional, keindahan bentang alam, gejala alam, peninggalan sejarah/budaya yang secara optimal untuk kesejahteraan masyarakat, (Dephut,2008). Mega biodiversitas yang ada di Indonesia dan menjadi Objek dan Daya Tarik Wisata Alam yang menarik salah satunya adalah keragaman tipe ekosistem hutan yang membentuk suatu tipe flora dan fauna serta bentangan alam (topografi) yang unik. (Fandeli, 2002:27). Keseluruhan potensi Objek dan Daya Tarik Wisata Alam yang ada merupakan sumber daya ekonomi yang bernilai tinggi dan sekaligus merupakan media pendidikan dan pelestarian lingkungan. 
Dalam rangka menemukan kembali dan mengembangkan Objek dan Daya Tarik Wisata Alam perlu segera dilaksanakan inventarisasi terhadap potensi Nasional Objek dan Daya Tarik Wisata Alam secara bertahap sesuai prioritas dengan memperhatikan nilai keunggulan saing dan keunggulan banding, kekhasan obyek, kebijaksanaan pengembangan serta ketersediaan dana dan tenaga. Tahap awal yang perlu dilakukan adalah menganalisa keseluruhan dari potensi Objek dan Daya Tarik Wisata Alam yang ada dalam bentuk kegiatan inventarisasi. Selanjutnya data-data tersebut dapat ditawarkan kepada pihak investor yang beminat untuk mengelola. Disinilah pelibatan pihak swasta dirasakan cukup diperlukan. Memang di satu sisi privatisasi kurang efektif dalam peningkatan ekonomi, namun kenyataan yang ada pengelolaan yang dilakukan pemerintah terutama yang terkait dengan pengelolaan jasa lingkungan dirasakan kurang efektif dalam penambahan devisa, justru cenderung merugi. Mengapa kita tidak mengalihkan privatisasi pengelolaan pariwisata ini ke pihak swasta yang dirasakan lebih profesional dalam me-menej suatu inventasi. Namun di negara kita justru sumber daya alam strategis justru dikelola oleh swasta.

Setelah mengetahui dan memahami karakter dan sifat dari Objek dan Daya Tarik Wisata Alam, maka barulah dapat disusun suatu kajian pengelolaan wisata alam dengan melibatkan semua pihak terkait. Pemahaman ekowisata juga tidak hanya terfokus pada Objek dan Daya Tarik Wisata Alam, namun juga aspek lain yang memerlukan kajian seperti, daya dukung lingkungan wisata. Semuanya dipadukan dalam suatu rancangan yang disebut RIPPOW (Rencana Induk Pengelolaan dan Pengembangan Objek Wisata). Azas kemanfaatan dari Objek dan Daya Tarik Wisata Alam dapat tercapai melalui pengelolaan dan pengusahaan yang benar dan terkoordinasi, baik lintas sektoral maupun swasta yang berkaitan dengan pengembangan kegiatan ekowisata, misalnya kepariwisataan, biro perjalanan, pemerintah daerah, lingkungan hidup, dan lembaga swadaya masyarakat (Dephut,2008).

Kesuksesan pengembangan ekowisata sangat ditentukan oleh peran dari masing-masing pelaku ekowisata yaitu; industri pariwisata, wisatawan, masyarakat lokal, pemerintah dan instansi non pemerintah, dan akademisi. Para pelaku ekowisata mempunyai peran dan karakter tersendiri yaitu dalam Suhanda, (2003:40).: Industri pariwisata yang mengoperasikan ekowisata merupakan industri pariwisata yang peduli terhadap pentingnya pelestarian alam dan keberlanjutan pariwisata dan mempromosikan serta menjual program wisata yang berhubungan dengan flora, fauna, dan alam. Wisatawannya merupakan wisatawan yang peduli terhadap lingkungan. Masyarakat lokal dilibatkan dalam perencanaan, penerapan danpengawasan pembangunan, dan pengevaluasian pembangunan. Pemerintah berperan dalam pembuatan peraturan-peraturan yang mengatur tentang pembangunan fasilitas ekowisata agar tidak terjadi eksploitasi terhadap lingkungan yang berlebihan. Akademisi bertugas untuk mengkaji tentang pengertian ekowisata dan mengadakan penelitian untuk menguji apakah prinsip-prinsi yang dituangkan dalam pengertian ekowisata sudah diterapkan dalam prakteknya. Pembangunan ekowisata yang berkelanjutan dapat berhasil apabila karakter atau peran yang dimiliki oleh masing-masing pelaku ekowisata dimainkan sesuai dengan perannya, bekerjasama secara holistik di antara para stakeholders, memperdalam pengertian dan kesadaran terhadap pelestarian alam, dan menjamin keberlanjutan kegiatan ekowisata tersebut.

Dalam pengelolaan Objek dan Daya Tarik Wisata Alam, terdapat beberapa faktor yang mempengaruhi kesuksesan pengelolaan nya diantaranya finansial, pemasaran produk serta aspek koordinasi. Murkana (1997: 21) menyebutkan Faktor utama yang menjadi persoalan dalam pengembangan objek dan daya tarik wisata pada umumnya terkendala pada aspek finansial. 
Biasanya investor bersedia menginvestasikan modalnya untuk pengembangan objek dan daya tarik wisata yang mempunyai potensi untuk dikembangkan.

Strategi pengembangan Objek dan Daya Tarik Wisata Alam meliputi pengembangan (Dephut, 2008): 1. Aspek Perencanaan Pembangunan Objek dan Daya Tarik Wisata Alam yang antara lain mencakup sistem perencanaan kawasan, penataan ruang (tata ruang wilayah), standarisasi, identifikasi potensi, koordinasi lintas sektoral, pendanaan, dan sistem informasi Objek dan Daya Tarik Wisata Alam. 2. Aspek Kelembagaan meliputi pemanfaatan dan peningkatan kapasitas institusi, sebagai mekanisme yang dapat mengaturberbagai kepentingan, secara operasional merupakan organisasi dengan SDM dan PP yang sesuai dan memiliki efisiensi tinggi. 3. Aspek Sarana dan Prasarana yang memiliki dua sisi kepentingan, yaitu (1) alat memenuhi kebutuhan pariwisata alam, (2) sebagai pengendalian dalam rangka memel ihara keseimbangan lingkungan, pembangunan sarana dan prasarana dapat meningkatkan daya dukung sehingga upaya pemanfaatan dapat dilakukan secara optimal. 4. Aspek Pengelolaan, yaitu dengan mengembangkan profesionalisme dan pola pengelolaan Objek dan Daya Tarik Wisata Alam yang siap mendukung kegiatan pariwisata alam dan mampu memanfaatkan potensi Objek dan Daya Tarik Wisata Alam secara lestari. 5. Aspek Pengusahaan yang memberi kesempatan dan mengatur pemanfaatan Objek dan Daya Tarik Wisata Alam untuk tujuan pariwisata yang bersifat komersial kepada pihak ketiga dan membuka lapangan kerja bagi masyarakat setempat. 6. Aspek Pemasaran dengan mempergunakan teknologi tinggi dan bekerja sama dengan berbagai pihak baik dalam negeri maupun luar negeri. 7. Aspek Peran Serta Masyarakat melalui kesempatan-kesempatan usaha sehingga ikut membantu meningkatkan kesejahteraan masyarakat. 8. Aspek Penelitian dan Pengembangan yang meliputi aspek fisik lingkungan, dan sosial ekonomi dari Objek dan Daya Tarik Wisata Alam. Diharapkan nantinya mampu menyediakan informasi bagi pengembangan dan pembangunan kawasan, kebijaksanaan dan arahan pemanfaatan Objek dan Daya Tarik Wisata Alam.

\section{METODE}

Jenis penelitian survey, yang menjadi populasi dalam penelitian ini melibatkan KetuaPanitia Bono, anggota Panitia event Bono, masyarakat tempatan dan wisatawan yang datang ke Kabupaten Pelalawan. Data yang diperoleh dari hasil observasi dan wawancara dipilah-pilah dan diklasifikasikan menurut jenisnya dan kemudian dianalisis serta diolah dengan menggunakan metode diskriptif analitik, yaitu dengan melakukan tabulasi terhadap data yang terkumpul, kemudian melakukan analisis baik secara komulatif maupun kualitatif mendapatkan gambaran dan disimpulkan secara deskritif yang sesuai dengan tujuan penelitian ini.

\section{HASIL}

Beberapa peselancar dunia pun telah menguji coba nyalinya dengan mengendarai papan selancar di atas ombak Bono ini. Hal ini kemudian berkembang menjadi suatu daya tarik wisatawan asing lainnya untuk mencoba ketangkasan mereka berselancar. Mengingat ombak Bono menjadi suatu ombak yang dianggap terbesar dari jenis ombak ini, maka suatu berkah yang sangat tak terhingga bagi masyarakat Desa Teluk Meranti - Pangkalan Kerinci khususnya, maupun Riau secara umumnya. Dan jika ini dikelola dengan baik akan menaikkan nama Indonesia di mata peselancar dunia, sehingga mereka tidak selalu berpikiran bahwa Bali adalah tempat berselancar terbaik di Indonesia. Ombak Bono pun menjadi lokasi berselancar yang terbaik di Indonesia. Provinsi Riau memiliki sektor pariwisata yang potensial tapi untuk 
mengelolanya secara optimal diperlukan kontribusi dan dukungan dari berbagai pihak, bukan cuma pemerintah daerah saja.Terutama untuk menyediakan infrastruktur memadai serta promosi yang gencar.

Berikut ini penulis sajikan beberapa strategi yang dilakukan oleh Dinas Pariwisata Kabupaten Pelalawan dalam memperkenalkan Kawasan Ombak Bono kepada masyarakat luas terutama wisatawan.

\section{Mengadakan Pagelaran Seni Budaya Kawasan Tirta Bono}

Pagelan Seni Budaya Kawasan Tirta Bono di Kecamatan Teluk Meranti ini berlangsung selama 3 hari, mulai dari tanggal 26 s/d 29 September 2011. Kegiatan ini diselengggarakan bekerjasama dengan kelompok Wisata Teluk Meranti yang diharapkan nantinya dapat menunjang kegiatan kepariwisataan Kawasan Tirta Bono, karena gelombang Bono saat ini sudah menjadi ikon wisata kabupaten Pelalawan.Sambutan masyarakat cukup antusias dengan penyelenggaraan Pagelaran Seni Budaya ini, dan bagi para tamu Peselancar dari berbagai Negara yaitu, Perancis, Jerman, Belgia, New Zealand, dan Swiss. Pagelaran ini sangat memuaskan dan mereka begitu terkesan dengan setiap penampilan yang dibawakan. Bagi mereka hal ini merupakan pengalaman yang sangat menarik dan membuat mereka ingin kembali dan mengetahui lebih banyak mengenai budaya tempatan.

Pagelaran yang berlangsung selama tiga malam tersebut, diikuti oleh beberapa Kecamatan, diantaranya adalah kecamatan Kerumutan dengan penampilan drama yang mengangkat tema “ Kembalikan Riau ku “. Kecamatan Ukui mengangkat tentang Budaya Silat Pedang, Silat Tangan Kosong dan Kopung Berempat. Kecamatan Pangkalan Lesung adalah Lukah gilo. Kecamatan Kuala Kampar dengan penampilan Joget Tandak Tanjung Selukop atau Joget Dangkong. Kecamatan Pangkalan Kuras menampilkan Badewo. Kecamatan Bandar Petalangan adalah Prosesi Menjaring Rusa, sedangkan sebagai Tuan Rumah kecamatan Teluk Meranti menampilkan atraksi "Drama Banjir Darah Mempusun", tarian dan Kolaborasi musik.

Untuk memeriahkan aktifitas Bono Surfing di Sungai Kampar Kecamatan Teluk Meranti, acara serupa akan di pagelarkan kembali pada akhir November 2012 mendatang dengan menampilkan kebudayaan lokal dan Tradisional dari Kecamatan Pangkalan Kerinci, Langgam, Bandar Seikijang, Bunut, dan Pelalawan. Semoga acara mendatang akan lebih berkesan sehingga dapat menjadi bahan promosi pendukung objek wisata Tirta Bono.

\section{Mengadakan Acara Promosi Wisata Gelombang Bono}

Agar Wisata Gelombang Bono ini lebih dikenal oleh masyarakat luas maka Pemerintah Kabupaten (Pemkab) Pelalawan melalui Dinas Pariwisata mengadakan acara promosi wisata gelombang bono pada tanggal 27 November 2011. Dalam acara ini Pemerintah Kabupaten (Pemkab) Pelalawan mengundang empat menteri dalam acara Promosi Wisata Gelombang Bono, Sungai Kampar. di Kecamatan Teluk Meranti. Empat menteri yang akan diundang antara lain, Menteri Pariwisata dan Ekonomi Kreatif Marie Elka Pangestu, Menteri Pekerjaan Umum (PU) Joko Kirmanto, Menteri Dalam Negeri (Mendagri) Gamawan Fauzi, dan Menteri Koordinaator Kesejahteraan Rakyat (Menkokesra) Agung Laksono.

Kedatangan para Menteri tersebut diyakini mampu memajukan wisata gelombang Sungai Kampar tersebut. Seperti Menteri Pariwisata dan Ekonomi kreatif, Marie E Pangestu, mampu mempublikasikan dan mengeksplorasi keindahan alam dimiliki Pelalawan. Kehadiran Menteri PU Joko Kirmanto, juga dapat memberikan solusi atas pembangunan jalan lintas bono sepanjang ratusan kilometer. Sebab saat ini, akses menuju Sungai Kampar masih tergolong sulit. Perkembangan objek wisata, berpengaruh besar terhadap pertumbuhan ekonomi warga sekitar dan mampu ditingkatkan kesejahteraannya melalui kedatang menkokesra. Terakhir, Mendagri 
Gamawan Fauzi bisa memantau perkambangan kabuapten Pelalawan dan kekayaan sumber daya alamnya.

Acara promosi ini direncanakan akan diadakan juga tahun 2013 dan juga setiap tahunnya, ini sudah dimasukkannya sebagai agenda kerja Pemerintah Kabupaten (Pemkab) Pelalawan. Dengan acara ini akan diharapkan bahwa Wisata Gelombang Bono akan semakin dikenal tidak saja di dalam negeri tetapi juga di luar negeri.

\section{Mengadakan Pameran Pariwisata}

Pameran pariwisata merupakan promosi sekaligus memasarkan pariwisata untuk mengenalkan obyek-obyek wisata yang dapat menarik minat wisatawan sehingga datang ke Kabupaten Pelalawan khususnya Wisata Tirta Bono. Melalui kegiatan pameran ini maka akan menambah wawasan bagi wisatawan terhadap obyek wisata kususnya Wisata Tirta Bono yang ada di Kabupaten Pelalawan. Disamping itu, pameran ini diharapkan sebagai upaya untuk lebih mengenalkan daerah tersebut ke dunia luar. Sehingga para wisatawan tertarik dan akhirnya mengunjungi obyek wisata yang dimaksud. Kegiatan pameran memberikan gambaran yang dapat menciptakan citra bagi daerah tujuan wisata yang bersangkutan.

Menarik tidaknya suatu kegiatan atau materi promosi obyek/atraksi wisata tidak saja tergantung pada desain atau visualisasi dari bahan-bahan promosi yang diberikan saat pameran. Namun juga pada tersampaikannya seluruh informasi yang dibutuhkan oleh calon wisatawan mengenai daerah tujuan yang akan dikunjunginya tersebut. Adapun aktivitas pameran yang telah dilakukan oleh Dinas Pariwisata Kabupaten Pelalawan antara lain : Pameran Pariwisata Kabupaten Pelalawan; Pameran pariwisata di Pekanbaru; Pameran Pekanbaru \& Riau Expo; Pameran Pekanraya di Jakarta.

\section{Meningkatkan sarana dan prasarana pariwisata}

Sarana dan prasarana pariwisata yang ada untuk menunjang Kawasan Wisata Tirta Bono sangat perlu diperhatikan oleh Pemerintah Kabupaten (Pemkab) Pelalawan seperti transportasi (jalan, jembatan), peningkatan daya tarik objek wisata, pengembangan sumber daya manusia dibidang pariwisata, peningkatan fasilitas dan pelayanan hotel, restoran, biro perjalanan sebagai penunjang keberhasilan peningkatan wisatawan.

\section{PEMBAHASAN}

Gelombang Bono merupakan salah satu keajaiban alam dan akan diprioritaskan menjadi Ikon Wisata Daerah. Saat ini Tirta Bono sudah berusaha semaksimal mungkin untuk menjadikan potensi Wisata Gelombang Bono dikenal mancanegara, bahkan Bupati Pelalawan telah mempromosikan sampai ke Dubai serta kerja sama dengan maskapai Penerbangan Garuda Indonesia. Sebagai bukti mulai banyaknya keinginan masyarakat untuk menyaksikan Bono secara langsung, pada tanggal 27 November 2011 yang merupakan hari puncak besarnya gelombang Bono, Kecamatan Teluk Meranti dipadati oleh masyarkat yang berkunjung dari beberapa daerah sekitar kecamatan Teluk Meranti dan daerah lain seperti Pekanbaru dan Pangkalan Kerinci. Pengunjung yang menyaksikan Bono terkonsentrasi dibeberapa tempat diantaranya: Pantai Ogis, dimana tempat ini paling ramai dikunjungi, Anjungan Pantau Bono, Tanjung Sesenduk, dan Tanjung Sebayang. Tempat tersebut merupakan lokasi posisi strategis, dimana masyarakat dapat menyaksikan Gelombang Bono datang sekaligus memecah.

Bono biasanya terjadi pada setiap tanggal 10-20 bulan Melayu dalam tahun Arab yang biasa disebut penduduk sebagai "Bulan Besar" atau "Bulan Purnama". Biasanya "gelombang Bono" atau "Ombak Bono" yang besar terjadi pada tanggal 13-16 bulan Melayu tahun Arab tersebut. Gelombang yang terjadi biasanya akan berwarna putih dan coklat mengikut warna air 
Kuala Kampar. Selain itu, Bono juga terjadi pada setiap "bulan mati" yaitu akhir bulan dan awal bulan (tanggal 1) Tahun Arab.Pada hari itu diperkirakan lebih dari 3000 orang yang datang berkunjung ke lokasi wisata Bono hanya untuk melihat Proses Gelombang Bono yang memecahkan tepian-tepian pantai Ogis, yang merupakan fenomena alam yang sangat unik. Masyarakat pun rela berpanas-panasan dengan kendaraan bermotor dari daerah masing-masing untuk mengunjungi Teluk Meranti daerah dimana Gelombang Bono berada. Kemungkinan besar mereka akan kembali untuk menyaksikan gelombang Bono ketika gelombang ini muncul lagi di bulan-bulan berikutnya.

Jadwal Terjadinya Bono Sungai Kampar 2012 ini dihitung berdasarkan kalender Bulan/Tahun Melayu atau Kalender Hijriyah 1433 - 1434 H (P) = Bulan Purnama / tengah bulan Melayu $(\mathrm{M})$ = Bulan Mati / awal bulan Melayu $(\mathrm{B})=$ Ombak Bono Sungai Kampar yang berukuran besar berkisar antara 4-6 meter. Selain itu biasanya berukuran sedang dengan ketinggian 3 meter. Keberadaan Kawasan Kawasan Bono di Kota Pelalawan mendatangkan wisatawan yang tidak sedikit untuk membelanjakan uangnya di Kota Pelalawan dengan asumsi akan meningkatkan pendapatan asli daerah sehingga perekonomian penduduk tempatan atau sekitarnya akan dapat lebih ditingkatkan.

Konsep ekowisata telah dikembangkan sejak era tahun 80-an, sebagai pencarian jawaban dari upaya meminimalkan dampak negatif bagi kelestarian keanekaragaman hayati, yang diakibatkan oleh kegiatan pariwisata. Konsep ekowisata sebenarnya bermaksud untuk menyatukan dan menyeimbangkan beberapa konflik secara objektif: dengan menetapkan ketentuan dalam berwisata; melindungi sumber daya alam dan budaya; serta menghasilkan keuntungan dalam bidang ekonomi untuk masyarakat lokal. Drumm (2002) dalam Suhanda (2003 : 33) menyatakan bahwa ada enam keuntungan dalam implementasi kegiatan ekowisata yaitu: Memberikan nilai ekonomi dalam kegiatan ekosistem di dalam lingkungan yang dijadikan sebagai obyek wisata; Menghasilkan keuntungan secara langsung untuk pelestarian lingkungan; Memberikan keuntungan secara langsung dan tidak langsung bagi para stakeholders; Membangun konstituensi untuk konservasi secara lokal, Nasional dan Internasional; Mempromosikan penggunaan sumber daya alam yang berkelanjutan; dan Mengurangi ancaman terhadap kenekaragaman hayati yang ada di obyek wisata tersebut.

Menurut Fandeli (2000:45), sifat dan karakter kepariwisataan alam terkait dengan Objek dan Daya Tarik Wisata Alam antara lain ; 1. In Situ ; Objek dan Daya Tarik Wisata Alam hanya dapat dinikmati secara utuh dan sempurna di ekosistemnya. Pemindahan objek ke ex situ akan menyebabkan terjadinya perubahan objek dan atraksinya. Pada umumnya wisatawan kurang puas apabila tidak mendapatkan sesuatu secara utuh dan apa adanya; $2 . \quad$ Perishable ; suatu gejala atau proses ekosistem hanya terjadi pada waktu tertentu. Gejala atau proses alam ini berulang dalam kurun waktu tertentu, kadang siklusnya beberapa tahun bahkan ada puluhan tahun atau ratusan tahun. Objek dan Daya Tarik Wisata Alam yang demikian membutuhkan pengkajian dan pencermatan secara mendalam untuk dipasarkan; 3. Non Recoverable ; suatu ekosistem alam mempunyai sifat dan perilaku pemulihan yang tidak sama. Pemulihan secara alami sangat tergantung dari faktor dalam (genotype) dan faktor luar (phenotype). Pemulihan secara alami terjadi dalam waktu panjang, bahkan ada sesuatu objek yang hampir tak terpulihkan, bila ada perubahan. Untuk mempercepat pemulihan biasanya dibutuhkan tenaga dan dana yang sangat besar, apabila upaya ini berhasil tetapi tidak akan sama dengan kondisi semula; 4. Non Substitutable ; didalam suatu daerah atau mungkin kawasan terdapat banyak objek alam, jarang sekali yang memiliki kemiripan yang sama. 
Pengelolaaan Objek dan Daya Tarik Wisata Alam dengan sifat dan karakter In Situ, cenderung memiliki daya tarik tersendiri.Objek dan Daya Tarik Wisata Alam ini biasanya mempunyai keterikatan yang kuat dengan habitat (ekosistem asli). Kita dapat melihat Onta di kebun binatang "Gembira Loka" Yogyakarta, namun kita akan merasa lebih puas jika datang ke habitatnya di benua Afrika. Kita akan merasa lebih puas melihat Gadjah seperti di Suaka Marga Satwa "Tesso Nilo", Provinsi Riau. Karena selain atraksinya, ekosistem alami juga dapat kita nikmati. Pengelolaan dengan pendekatan ekosistem inilah sebenarnya yang perlu dilakukan dalam rangka pelestarian sifat Objek dan Daya Tarik Wisata Alam secara In Situ.

\section{SIMPULAN}

Daya Tarik Wisata Bono sangat mengagumkan dan tidak ada tandingannya sehingga mampu menarik minat wisatawan datang ke Kabupaten Pelalawan.Bagi dunia peselancar (surfer) maupun wisatawan dari luar, Ombak Bono Kampar adalah sebuah penemuan yang mengagumkan bahkan para selencar dunia mengungkapkan luar biasa untuk "Bono Kampar". Dulu Ombak Bono atau gelombang Sungai Kampar sebagai sosok yang menakutkan, tetapi kini justru menjadi Wisata Andalan bagi Pelalawan dan juga Provinsi Riau. Strategi Pemerintah Kabupaten untuk mengembangkan Kawasan Wisata Bono Sebagai wisata andalan Di Kabupaten Pelalawan sudah dilakukan dengan baik namun belum maksimal. Strategi yang telah dilakukan untuk mengembangkan kawasan tersebut adalah: Mengadakan pagelaran seni budaya kawasan Bono, Mengadakan acara promosi Gelombang Bono, Mengadakan pameran pariwisata dan Meningkatkan sarana dan prasarana pariwisata.

\section{DAFTAR PUSTAKA}

Australian National Ecotourism Strategy, 1994, Peranan Ekowisata Dalam Kehidupan, Gramedia, Jakarta

Ashrama. 2003, Objek Dan Daya Tarik Wisata Alam, Gramedia, Jakarta

Brosur Dinas Kebudayaan Pariwisata Pemuda Dan Olahraga. 2012, Objek Wisata Bono Sungai Kampar, Kabupaten Pelalawan

Blangey Dan Wood In Wall. 1995), Ecotourism Envolvestraveling, Gramedia, Jakarta

Ceballos - Lascurian. 1995, Pariwisata Dan Perjalanan, Ghalia,Jakarta

Dephut. 2008, Potensi Obyek Dan Daya Tarik Wisata Alam (ODTWA), Jakarta

Ditjen PHKA. 2005, Strategi Pengembangan Produk Dan Promosi Ekowisata, Jakarta

Entin Supriatin, 21 Oktober 1997, Lima Unsur Dalam Pengelolaan Ekowisata, Berita Wisata, Jakarta

Fandeli. 2000, Wisata Berbasis Ekologi, Alfabetha, Bandung

Ghufron Azhar. 2005, Ekowisata Dalam Kaitannya Dengan Program Studi, Gramedia, Jakarta 
Hector Cebollos Lascurain. 1997, Ecotourism, Alfabetha, Bandung

Happy Marpaung, 2002, Gejala Pariwisata, Alfabetha, Bandung.

Khan. 2003, Perjalanan Wisata, Gramedia, Jakarta

Murkana. 1997, Pengelolaan Daerah Tujuan Wisata, Ghalia, Jakarti

Ma. Desky, 2000, Manajemen Perjalanan Wisata, Adicita, Yogyaka:

Oka. A. Yoeti. 1996. Pengantar Pariwisata. Gramedia Pustaka Utama. Jakarta. , 1999, Pemasaran Pariwisata Terpadu, Angkasa, Bandung. , 2001, Tours And Travel Management, Pradnya Paramita, Jakarta.

Subadra. 2007, Konsep Ekowisata, Yudhistira, Jakarta

Santoso. 2003, Unsur-Unsur Dalam Ekowisata, Gramedia, Jakarta

Suhanda. 2003, Implementasi Kegiatan Ekowisata, Gramedia, Jakarta

Sumadi Suryabrata. Metodologi Penelitian, Rajawali Pers, Jakarta, 1992.

The Ecotourism Society. 2002, Ekowisata Dalam Kepariwisataan, Jakarta 